\title{
Kepentingan Nilai-nilai Islam dalam Pembangunan Diri Orang Kelainan Upaya (OKU) Kategori Bermasalah Pembelajaran
}

\author{
Yusmini Md Yusoff \\ Universiti Malaya, yusmini@um.edu.my \\ Azura Awang \\ Institut Pendidikan Guru Bangi, azura1598@gmail.com \\ DOI: https://doi.org/10.22452/usuluddin.sp2019no1.5
}

\begin{abstract}
Abstrak
Pembangunan insan adalah aspek yang dititikberatkan oleh Islam dalam proses pendidikan yang merangkumi perkara asas seperti akidah, ibadah dan akhlak. Perkara asas ini perlu dididik dan diterapkan bukan sahaja kepada individu normal tetapi juga kepada mereka yang kurang bernasib baik seperti orang kurang upaya (OKU) agar golongan ini mempunyai garis panduan yang mencukupi untuk melayari kehidupan sebagai OKU Muslim. Dalam konteks artikel ini, perbincangan pembangunan insan adalah tertumpu kepada diri OKU dalam kategori bermasalah pembelajaran. Perbincangan dimulakan dengan memahami ciri-ciri ketidakupayaan yang dialami oleh golongan ini dan seterusnya komponen nilai-nilai Islam yang boleh diterapkan mengikut tahap keperluan dan kemampuan mereka.
\end{abstract}

Kata kunci: pembangunan diri, OKU bermasalah pembelajaran, nilainilai Islam

\section{The Importance of Islamic Values toward Self Development of Disabled People with Learning Ability Category}

\section{Abstract}

In Islamic paradigm, the development of self is an important aspect within its educational process. Matters such as faith, worships and moral values are considered fundamental to be taught and employed not only to regular individuals but also to the less fortunate such as the disabled. These values are regarded as guidelines for them in navigating their lives as disabled Muslim individuals. In the context of this article, the discussion will be more on disabled persons with learning ability category. Their characteristics of disabilities will be brought forward to understand better of their current situation, and what kind of Islamic values that can be employed to their level of needs and capabilities.

Keywords: self-development, disable people with learning disability, Islamic values 


\section{Pendahuluan}

Dalam Islam, pembangunan diri bermula dengan tarbiah atau pendidikan yang berlandaskan kepada Al-Quran dan Al-Sunnah. Pendidikan ini bermula seawal janin berada dalam kandungan sehinggalah individu tersebut berhadapan dengan kematian. Tujuan pendidikan dalam Islam adalah untuk membentuk khalifah Allah yang bertanggungjawab mengurus semua penciptaan tuhan dengan baik dan dalam masa yang sama mampu berfungsi sebagai hamba yang taat kepada segala perintahNya. Oleh yang demikian, urusan mendidik perlu diberikan kepada semua anggota masyarakat tanpa mengambil kira aspek sosial, ekonomi, latar belakang budaya, gender atau tahap kemampuan seseorang individu itu. Ia termasuk mereka yang tergolong dalam kategori kurang upaya atau kelainan upaya (OKU). Untuk golongan OKU, tarbiah dilaksanakan untuk memberi kefahaman terhadap Islam dan nilai-nilai yang terkandung di dalamnya supaya ia dapat disemai dengan baik dan boleh menjadi garis panduan buat mereka dalam melayari kehidupan sebagai OKU Muslim.

Namun, dalam proses pembangunan diri OKU terdapat pelbagai cabaran dan halangan yang perlu dihadapi. Salah satu daripada cabaran tersebut ialah berhadapan dengan persepsi masyarakat. Lazimnya ekspresi yang ditunjukkan terhadap golongan ini sering bersifat negatif dan kurang terbuka. Perkara ini mungkin berlaku kerana secara tipikal OKU dianggap sebagai ahli yang tidak mampu menyumbang kepada ahli-ahli lain dalam masyarakat berkenaan. Malah ada sebahagian yang berpandangan golongan ini menjadi liabiliti atau beban kepada mereka dan bukan aset yang perlu dibimbing dan dihargai ${ }^{1}$. Persepsi bahawa golongan ini tidak perlu dibimbing terutama dalam aspek pendidikan Islam hanya kerana mereka cacat, tidak berupaya memahami dan membebankan perlu ditangani dengan baik. Hal ini termasuk sejauh mana penerimaan ibu bapa terhadap anak-anak golongan $\mathrm{OKU}^{2}$.

1 Kelsey Lisle, "Identifying the Negative Stigma Associated with Having a Learning Disability"(Honors Thesis, Bucknell University, 2011), 3-5.

2 Azmi Shaari, Noor Hayati Che Harun dan Tengku Noaswita Tengku Besar, "Faktor yang Mempengaruhi Penglibatan Keluarga Penjaga di Sekolah dan Kesannya ke atas Pencapaian Akademik Anak Cacat Penglihatan", Jurnal Pembangunan Sosial (4\&5, Jun \& Disember, 2002), 15-26. Lihat juga Helen Leonard et al., "Transition to Adulthood for Young People with Intellectual 
Penerimaan ibu bapa terhadap anak-anak OKU adalah sangat signifikan kerana ia mencorak motivasi dan usaha mereka dalam menyediakan pendidikan Islam yang berkesan serta suasana kondusif untuk pendidikan tersebut. Ibu bapa yang kurang mementingkan pendidikan agama sehingga mengambil sikap tidak peduli dan membiarkan sahaja anak tanpa ilmu yang sewajarnya perlu dibantu dan diberi panduan kerana mereka merupakan tonggak utama dalam pembangunan diri keluarga. Apatah lagi sekiranya anak tersebut bukan sahaja berada dalam kategori kelainan upaya yang melibatkan kehilangan deria atau anggota badan (cacat fizikal) tetapi juga mengalami masalah ketidakupayaan akal (kognitif) seperti bermasalah pembelajaran, lembam, autisme atau down syndrome.

Dalam hal ini, Gulson Begum Khalid dan Mohd Hanafi Mohd Yasin mendapati ibu bapa sering bingung untuk membimbing anak-anak kelainan upaya jenis ini kerana kecacatan yang dialami sukar ditangani berbanding anak-anak OKU cacat anggota badan ${ }^{3}$. Walau bagaimana pun, peranan menerapkan nilainilai Islam terhadap anak-anak berkenaan tidak boleh diabaikan kerana potensi untuk mereka terlibat dengan masalah sosial dan akhlak tetap $\operatorname{ada}^{4}$. Justeru, penulisan artikel ini bertujuan untuk mengetengahkan aspek-aspek penting dalam pendidikan Islam OKU bermasalah pembelajaran. Perbincangan dimulakan dengan memberi gambaran umum berkaitan ciri-ciri golongan OKU bermasalah pembelajaran dan seterusnya komponen nilai-nilai Islam yang boleh diterapkan dalam pendidikan untuk golongan tersebut.

\section{Memahami OKU Bermasalah Pembelajaran}

Secara asasnya, OKU bermasalah pembelajaran adalah mereka yang tidak sempurna dalam aspek berfikir, mendengar, membaca, bercakap dan menulis menyebabkan mereka memerlukan

Disability: The Experience of their Families”, Eur Child Adolesc Psychiatry (25, 2016), 1369-1381

3 Gulson Begum Khalid dan Mohd Hanafi Mohd Yasin, "Strategi Menjayakan Penglibatan Ibu Bapa di Sekolah Pelajar Berkeperluan Khas" (makalah, Seminar Internasional Pasca-Siswazah Pendidikan Khas UKM-UPI Siri II, 28 Januari 2012), 665.

4 Suppiah Nachiappan et al., Pembelajaran dan Perkembangan Pelajar (Edisi ke-2, Selangor: Oxford Pelajar, 2012), 76-77. 
pendidikan yang bersifat khusus. Oleh kerana ciri-ciri tersebut, kumpulan OKU ini dikategorikan juga sebagai individu berkeperluan khas. Ciri-ciri ketidakupayaan akal (kognitif) yang dialami merupakan faktor kepada beberapa masalah tingkah laku, neuro (saraf), psikologi dan komunikasi dengan persekitaran ${ }^{5}$. Walau pun mengalami kerencatan akal namun tahap kerencatan tersebut masih membolehkan individu itu dididik (educable mentally retarded). Ini kerana OKU bermasalah pembelajaran mampu untuk mengikuti pembelajaran di peringkat paling asas dengan kebolehan pembelajaran minimum ${ }^{6}$. Dalam hal ini, Normah Che Din menyatakan kebanyakan OKU bermasalah pembelajaran tidak menguasai pencapaian dalam skor ujian aptitud dan ujian pencapaian akademik. Mereka mengalami kecelaruan psikologi namun tidak mempunyai masalah yang mengganggu perkembangan diri yang lain. Mereka mungkin melalui proses perkembangan yang lambat seperti dyslexia, dysgraphia atau dyscalculia. Perkembangan-perkembangan lambat ini adalah jenis-jenis penyakit yang menyebabkan kesukaran dalam aspek pembelajaran seperti membaca, mengira dan menulis sama ada secara visual atau audio yang menyebabkan pencapaian akademik mereka lemah ${ }^{7}$.

Tingkah laku OKU bermasalah pembelajaran tidak banyak berbeza dengan individu normal lain. Namun, ada ketikanya OKU ini cenderung untuk memperlihatkan tingkah laku yang bertentangan dengan norma pembelajaran sedia ada seperti bersikap submisif, terlalu pemalu dan sensitif, sangat tidak berminat dengan pelajaran dan kadang-kadang kelihatan

\footnotetext{
Saedah Sumrah, Salwan Sudirman dan Roslee Ahmad, "Kaedah Menangani Kanak-kanak Bermasalah Tingkahlaku" (makalah, Seminar Kaunseling Keluarga, Universiti Teknologi Malaysia, Skudai, Johor, 30 Ogos 2008), 91.

6 Saedah Sumrah, Salwan Sudirman dan Roslee Ahmad, "Kaedah Menangani Kanak-kanak Bermasalah Tingkahlaku", 361. Lihat juga Sandra Baum, "The Use of Systemic Approach to Adullts with Intellectual Disabilities and their Families: Historical Overview and Current Research", In Sandra Baum and Henrik Lynggaard, Intellectual Disabilities: A Systemic Approach (London: Routledge, 2018), 22-23.

7 Normah Che Din, "Kepentingan Penilaian Profil dan Keperluan Kanak-Kanak Istimewa" (makalah, Seminar Pendidikan Anak-Anak Istimewa dalam Islam, Institut Kefahaman Islam Malaysia, Kuala Lumpur, 21-22 Ogos, 2014), 8-12.
} 
berkhayal $^{8}$. Walau pun ada dalam kalangan mereka yang boleh bergaul secara normal dengan individu lain, namun akibat sering dilabelkan sebagai bodoh, lembam dan pemalas, mereka memilih untuk mengelak daripada terlibat dengan interaksi sosial. Lazimnya OKU bermasalah pembelajaran boleh memberi tumpuan kepada sesuatu dorongan atau keinginan tetapi dalam kadar waktu yang singkat. Ingatan yang lemah dan mudah terkeliru dengan sesuatu perkara menyebabkan perhatian mereka terganggu. Faktor kecacatan ini sedikit sebanyak menyukarkan OKU bermasalah pembelajaran menerima pengetahuan tentang nilai-nilai Islam. Ini berikutan individu tersebut mudah lupa akibat ingatan jangka pendek dan kurang kemampuan untuk fokus kepada sesuatu perkara9.

Isu lain yang dihadapi adalah masalah dalam mengawal emosi. Faktor ini serba sedikit mengganggu pembentukan rohani atau jiwa OKU bermasalah pembelajaran. Kegagalan mengawal emosi berlaku disebabkan rasa rendah diri akibat pembelajaran yang lemah menyebabkan mereka sering mengalami masalah psikologi seperti kurang keyakinan, malu, putus asa dan tidak kurang juga yang mengalami kemurungan ${ }^{10}$. Akibat kekurangankekurangan tersebut, terdapat ibu bapa yang terlalu memanjakan anak sehingga segelintir OKU ini kurang kemampuan untuk berdikari dan terdapat dalam kalangan mereka yang terlibat dengan tingkah laku tidak bermoral. Sehubungan itu, amalan dan cara hidup OKU bermasalah pembelajaran perlu dipupuk dengan baik bermula di rumah. Soal agama dan nilai-nilai Islam perlu dititikberatkan supaya nilai-nilai murni dalam agama dapat membantu golongan ini berakhlak dan berperilaku mulia dengan memperkukuhkan aspek akidah, ibadah dan akhlak OKU bermasalah pembelajaran.

8 Normah Che Din, "Kepentingan Penilaian Profil dan Keperluan Kanak-Kanak Istimewa", 12.

9 Jamila K.A. Mohammed Kutty, Mohd Hanafi Mohd Yasin dan Rosadah Abd Majid, "Pelaksanaan Pengajaran Kemahiran Membaca dan Menulis bagi Murid Murid Pra-Sekolah Bermasalah Pendengaran”, Jurnal Pendidikan Bahasa Melayu (2011), 117.

10 Normah Che Din, "Kepentingan Penilaian Profil dan Keperluan Kanak-Kanak Istimewa", 8-12. 


\section{Komponen Nilai-nilai Islam dalam Pembangunan Diri OKU Bermasalah Pembelajaran}

Islam percaya bahawa setiap individu yang dilahirkan adalah bersih dan suci seperti yang dijelaskan dalam hadith yang bermaksud $^{11}$ :

Dari Abu Hurairah (ra) berkata, Rasulullah SAW bersabda: Setiap anak dilahirkan dalam keadaan fitrah. Maka ibu bapalah yang menjadikannya Yahudi, Nasrani atau Majusi sebagaimana binatang ternak yang melahirkan binatang ternak [anak] dengan sempurna...

Berdasarkan hadith di atas, ibu bapa sebagai individu yang melahirkan adalah pemegang amanah yang bertanggungjawab untuk mencorakkan diri anak-anak mengikut acuan yang ditetapkan. Dalam Islam, acuan tersebut merupakan ajaran agama yang disandarkan kepada petunjuk Al-Quran dan panduanpanduan yang terdapat dalam sunnah Rasulullah SAW. Bagi OKU bermasalah pembelajaran, penerapan nilai-nilai Islam adalah untuk mencetuskan celik iman. Kecelikan iman merupakan satu kesedaran menjalani kehidupan beragama berasaskan kefahaman akidah yang betul. Kefahaman ini diharapkan mampu membentuk sikap dan peribadi yang sesuai untuk mereka berinteraksi dengan baik apabila bersama keluarga dan masyarakat sekeliling. Dalam erti kata lain, minda, jiwa dan emosi golongan ini perlu diisi dengan nilai-nilai Islam supaya anasir-anasir luaran yang tidak serasi dan negatif boleh ditepis dan tidak mempengaruhi tingkah laku golongan tersebut. Tambahan pula, mendapat didikan dan asuhan secara Islam merupakan hak yang perlu diberikan kepada mereka. Penafian hak ini boleh menjurus kepada lemahnya jiwa, hilang keyakinan diri serta identiti diri sebagai seorang Muslim.

Dalam hal ini, Deklarasi Tentang Hak Anak-anak menegaskan bahawa hak anak untuk mendapatkan pendidikan yang sihat adalah berdasarkan kepada nilai akhlak mulia dan pekerti yang luhur ${ }^{12}$. Sama seperti anak normal, anak-anak OKU

11 Abū 'Abd Allāh Muhammad bin Ismā‘̄il al-Bukhārī, Jāmi' al-Musnad al-Ṣaḥ̄ḥ al-Mukhtașar Min Umūrī Rasul Allāh SAW wa Sunanihi wa Ayyāmih, "Ṣaḥịh al-Bukhārī”, e.d Muhammad Zuhayr bin Nāṣir al-Nāṣir (Mansurah: Dār Ṭūqā al-Najah, 2001), 2:94-95.

12 Subhi Mahmassani, Konsep Dasar Hak-hak Asasi Manusia: Studi Perbandingan Syariat Islam dan Perundangan Moden (Indonesia: Pt. Tintamas, 1979), 203. 
bermasalah pembelajaran perlu dipupuk konsep kendiri, nilai peribadi dan motivasi yang tinggi supaya mereka tidak terdedah kepada sebarang pengabaian, penganiayaan dan penderaan sama ada dari segi fizikal, mental atau emosi. Memberi perlindungan, bersikap mesra, berlaku adil, memahami perubahan fizikal, perkembangan tingkah laku dan emosi tanpa membezakan mereka dengan anak-anak normal yang lain adalah antara cara membina daya tahan dan kendiri anak-anak tersebut ${ }^{13}$.

Untuk tujuan itu, OKU bermasalah pembelajaran yang memiliki tahap kerencatan mental ringan atau sederhana - yang boleh dididik dan dirawat, walau pun mengalami sedikit gangguan dalam berkomunikasi dan berinteraksi, berpotensi untuk menerima nilai-nilai Islam dengan bimbingan yang sesuai ${ }^{14}$. Ini adalah kerana, mereka yang juga dikategorikan sebagai slow learner masih mempunyai keupayaan untuk memahami konsep atau nilainilai asas dalam Islam. Walau bagaimana pun, cara atau kaedah untuk menerapkan nilai-nilai tersebut perlulah bersifat dinamik dan fleksibel mengikut tahap keperluan dan kemampuan mereka, sesuai dengan pandangan al-Shaybani yang menyatakan mendidik anak-anak berkaitan dasar-dasar agama hendaklah seiring dengan tahap kematangan, kefahaman dan realiti (keadaan) anak-anak tersebut $^{15}$. Dalam konteks ini, sesuatu pengetahuan yang disampaikan mengikut kemampuan anak bukan diajar berdasarkan peningkatan usia tetapi mengikut penerimaan akal fikiran dengan menggilap potensi yang dimiliki secara beransur-ansur, berperingkat serta mudah agar ia tidak membebankan anak tersebut ${ }^{16}$.

Bagi OKU kategori bermasalah pembelajaran, terdapat tiga komponen asas dalam proses penerapan nilai-nilai Islam yang perlu ditekankan iaitu akidah, ibadah dan akhlak. Dari perspektif Islam, komponen asas ini adalah sama untuk individu normal lain

13 Sharifuddin Aisa Osman, "Menangani Gejala Sosial: Peranan Keluarga", dalam Keluarga Islam, Kemahiran Keibubapaan dan Cabaran Semasa, peny. Azrina Sobian (Selangor: MPH Group Publication, 2008), 282.

14 Mohd Zuri Ghani dan Aznan Che Ahmad, Pengantar Pendidikan Khas (Pulau Pinang: Universiti Sains Malaysia, 2011), 160.

15 Omar Muhammad al-Toumy al-Syaibani, Falsafah Pendidikan Islam, terj. Hasan Langgulung, (Selangor: Hizbi Sdn. Bhd., 1991), 47.

16 Ab. Aziz Mohd Zin et al., Dakwah Islam Terhadap Orang Kurang Upaya (Kuala Lumpur: Universiti Malaya, 2009), 113. 
tetapi ia berbeza dari sudut kaedah dan cara penyampaiannya. Pengaruh nilai-nilai ini kepada OKU bermasalah pembelajaran juga mungkin berbeza mengikut tahap tumbesaran dan perkembangan mereka. Perbincangan berkaitan nilai-nilai ini dalam konteks OKU bermasalah pembelajaran adalah seperti berikut:

\section{Nilai Akidah}

Akidah memfokuskan nilai-nilai keimanan yang berpaksikan tauhid dan pengEsaan kepada Allah SWT. Aspek ini boleh dilatih dengan merangsang pemikiran individu OKU tentang penciptaan Allah SWT yang boleh mereka lihat, dengar dan sentuh. Alam semulajadi seperti tanah, pokok, haiwan peliharaan dan seumpamanya boleh menjadi bahan pembelajaran untuk tujuan ini. Pemerhatian terhadap anggota badan serta fungsinya kepada manusia juga boleh menghidupkan kesedaran tentang nikmatnikmat yang diberikan oleh Allah SWT. Langkah seperti ini melahirkan rasa syukur di atas kurniaan anggota badan sekaligus mengingatkan mereka supaya tidak menyalahgunakan anggotaanggota tersebut untuk tujuan kemaksiatan. Nilai keimanan seperti ini menimbulkan celik akal bahawa Allah SWT sentiasa memerhati segala tingkah laku hambaNya serta mendidik OKU bermasalah pembelajaran supaya berhati-hati apabila timbul keinginan untuk melakukan kemungkaran.

Selain itu, memperkenalkan nama-nama Allah atau zikir-zikir pendek secara santai melalui alunan nasyid dan nyanyian merupakan salah satu kaedah dalam memperkukuhkan akidah OKU bermasalah pembelajaran ${ }^{17}$. Menyemai perasaan cinta kepada Allah dan para nabiNya boleh dilakukan tanpa melibatkan elemen kognitif yang berat dan sukar seperti mengajar selawat yang paling ringkas dan mudah diingati. Perkara ini merupakan latihan dan pengajaran yang perlu dilakukan secara berterusan supaya elemen pengulangan terhadap sesuatu nilai akidah yang ingin diterapkan dapat dijalankan secara optimum dan berkesan.

2. Nilai Ibadah

Pelaksanaan ibadah kepada OKU bermasalah pembelajaran melambangkan kefahaman dan kepatuhan kepada ajaran Islam.

17 Ab. Aziz Mohd Zin et al., Dakwah Islam Terhadap Orang Kurang Upaya, 160. Lihat juga Ramlan Salim, Pengurusan Pendidikan Khas Bermasalah Pembelajaran (Kuala Lumpur: Dewan Bahasa dan Pustaka, 2015), 3. 
Dasar utama ibadah dalam Islam ialah melaksanakan perkaraperkara wajib dan meninggalkan perkara-perkara haram. Seperti aspek akidah, amalan ibadah kepada golongan ini perlu disesuaikan dengan tahap perkembangan akal dan naluri mereka. Sabda Rasulullah SAW yang bermaksud ${ }^{18}$ :

Kami para nabi, diperintahkan agar meletakkan manusia sesuai dengan kedudukan mereka dan kami juga diperintahkan supaya berbicara dengan manusia mengikut kadar kemampuan mereka.

Amalan ibadah yang dirangkumkan dalam taklif rukun Islam merupakan pendekatan untuk membangunkan nilai spiritual insan serta satu bentuk pengabdian diri yang menjadi manifestasi iman dan takwa kepada Allah SWT. Ibadah dalam Islam dapat membentuk sifat mulia dan peribadi mukmin sejati. Justeru, mendirikan solat adalah penekanan awal yang dituntut kepada setiap individu Muslim. Solat jika dilakukan dengan niat dan tujuan yang benar mampu memberi impak kepada pembangunan fizikal, roh, emosi dan akal manusia. Pembangunan keempatempat aspek ini mempengaruhi keseimbangan pembangunan diri OKU bermasalah pembelajaran.

Oleh kerana kecacatan OKU bermasalah pembelajaran sedikit sebanyak menyumbang kepada kesukaran untuk mendidik mereka berkaitan solat, pendekatan yang digunakan haruslah berbentuk praktikal dan latih tubi. Pendekatan tunjuk cara atau role modelling dan arahan langsung (direct instruction) disifatkan sebagai kaedah yang paling berkesan supaya amalan solat bukan berbentuk retorik semata-mata sebaliknya diamalkan dengan penuh kesedaran dan kesungguhan ${ }^{19}$. Ia perlu diajar lebih daripada sekali dan mengambil masa yang agak lama berikutan penerimaan kognitif OKU bermasalah pembelajaran yang perlahan. Kaedah tunjuk ajar adalah sesuai kerana sifat dan keinginan untuk meniru (imitate) sesuatu tingkah laku adalah lebih mudah diterap daripada menerangkan sesuatu secara lisan. Contoh tunjuk ajar adalah seperti mengimamkan solat dan menguatkan bacaan supaya perbuatan yang dilakukan dapat dilihat dan didengar dengan jelas

18 Omar Muhammad al-Toumy al-Syaibani, Falsafah Pendidikan Islam, 601.

19 Muhammad Khair Ramadan Yusuf, Kisah Luqman al-Hakim dan Kebijaksanaannya, terj. Ibnu Ghazali, Buku 2 (Selangor: Jasmin Enterprise, 2006), 46 
oleh OKU bermasalah pembelajaran. Pendekatan ini juga boleh digunakan untuk bimbingan cara mengambil wuduk, melaungkan azan, menyucikan diri (mandi hadas), menjaga kebersihan diri dan membaca al-Quran.

\section{Nilai Akhlak}

Di samping pembangunan akidah dan ibadah, penumpuan terhadap pendidikan akhlak juga penting kepada golongan OKU bermasalah pembelajaran. Terdapat lima aspek yang perlu dititikberatkan dalam perkara ini iaitu ${ }^{20}$ :

i. Akhlak dalam kehidupan.

ii. Akhlak dalam bersosial atau berinteraksi dengan manusia.

iii. Akhlak ketika menunaikan ibadah.

iv. Akhlak dalam menuntut ilmu.

v. Akhlak terhadap Allah SWT dan Rasulullah SAW.

Akhlak dalam kehidupan adalah seperti menjaga adab makan, adab tidur, adab memasuki tandas, menaiki kenderaan dan seumpamanya. Manakala akhlak dalam bersosial bermaksud menjaga perilaku sesama rakan, ibu bapa, keluarga dan masyarakat sekeliling. Nilai-nilai akhlak dalam konteks ini lebih menjurus kepada konsep berkasih sayang, menahan amarah, berkata benar, saling bermaaf-maafan, berlemah lembut, menanam sifat sabar dan menjalin ukhuwah ${ }^{21}$. Ahmad al-Qattan menegaskan tujuan pendidikan akhlak adalah supaya manusia dapat berhubungan dengan baik dengan mengawal tingkah laku yang tidak sesuai ${ }^{22}$.

Dalam situasi OKU bermasalah pembelajaran, pendidikan akhlak membantu mereka untuk belajar berdikari tanpa mempunyai rasa malu yang keterlaluan ekoran kekurangan diri yang dialami. Dengan akhlak yang baik serta sesuai dengan norma masyarakat setempat, OKU bermasalah pembelajaran lebih mudah diterima sebagai salah seorang ahli yang perlu disokong, dilindungi dan disayangi. Hal ini memudahkan mereka bergerak

20 Abdul Hafiz Mat Tuah, Zakaria Stapa dan Ahmad Munawar, "Memperkasakan Jati Diri Melayu-Muslim Menerusi Pendidikan Islam dalam Pengajaran Akhlak", Jurnal Hadhari (2012), 31.

21 Wan Nasyruddin Wan Abdullah dan Hisham Ahmad, Aku Bersyukur Anakku Autisme (Kuala Lumpur: Telaga Biru, 2013), 103-121.

22 Ahmad al-Qattan, Pendidikan Anak Cemerlang Menurut al-Quran dan alSunnah, terj. Ahmad Najib Abdullah al-Qari (Selangor: Pustaka Ilmi, 1998), 138-146. 
dengan lebih bebas dan selamat tanpa pengawasan penuh daripada ibu bapa atau individu terdekat. Selain itu, mereka yang dididik dengan sifat bertimbang rasa, bertindak dengan cara yang benar dan berkeyakinan sedikit sebanyak boleh mempertahankan diri jika berhadapan dengan situasi-situasi yang tidak diingini seperti dibuli atau dianiaya.

Penekanan yang perlu diberikan dalam membangunkan akhlak OKU bermasalah pembelajaran ialah nilai seseorang terletak kepada agama dan akhlaknya, bukan kepada kekurangan dan kecacatan yang boleh melemahkan semangat mereka ${ }^{23}$. Kepentingan pendidikan akhlak kepada golongan ini adalah untuk mengelakkan perasaan putus asa dengan kekurangan diri akibat tiada pengetahuan dan kawalan agama. Ia juga membolehkan individu OKU bermasalah pembelajaran membuat pertimbangan terhadap apa-apa tindakan yang diambil sama ada tindakan tersebut betul atau salah sebagai panduan dalam menjalani kehidupan bersyariat. Hakikatnya, jati diri seseorang termasuk golongan OKU tidak dapat dibentuk tanpa nilai-nilai murni dalam diri. Nilai-nilai Islam seperti yang dibincangkan sebelum ini harus dipupuk secara konsisten untuk melahirkan insan OKU yang berpekerti tinggi dan mulia di sisi Allah SWT seiring dengan firmanNya:

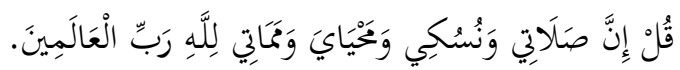

Al-An'ām 6:162

Katakanlah: Sesungguhnya sembahyangku, ibadahku, hidupku dan matiku hanyalah untuk Allah, tuhan yang memelihara dan mentadbir sekalian alam.

Asasnya pendidikan dan penerapan nilai-nilai Islam OKU bermasalah pembelajaran memerlukan kerjasama secara kolektif dari pelbagai pihak. Sokongan sosial yang kuat menjadikan golongan OKU termasuk ibu bapa dan keluarga mereka lebih cekal dan tabah dalam usaha penerapan nilai-nilai Islam. Sikap masyarakat yang prihatin, menerima seadanya, bersimpati, mengambil berat serta memahami kesukaran yang dialami OKU akibat daripada kecacatan akan melahirkan rasa dihargai dan

${ }^{23}$ Khairul Hamimah Mohammad Jodi, Mohd Fauzi Hamat dan Hadenan Towpek, "Nilai-nilai Islam dalam Program Pemulihan Banduanita di Penjara", Jurnal Usuluddin 35 (2012), 99-116. 
selamat. Suasana harmoni seperti ini lebih memudahkan OKU dan keluarga mereka untuk terus bersemangat menyertai masyarakat secara inklusif bagi meneruskan kehidupan dengan amalan dan pegangan yang berteraskan Islam. Ini adalah kerana kehidupan bersyariat bukan sahaja terpakai kepada individu normal tetapi juga kepada mereka yang memiliki ketidakupayaan tertentu. Dalam konteks OKU bermasalah pembelajaran, walau pun golongan ini dianggap sebagai slow learner, mereka tidak harus dibiarkan ketinggalan dalam usaha membangunkan nilai-nilai Islam dalam diri.

\section{Penutup}

Model pendidikan dalam Islam adalah komprehensif dengan alQuran dan al-Sunnah sebagai teras kepada usaha pembangunan nilai-nilai Islam. Untuk OKU bermasalah pembelajaran, selain daripada ilmu-ilmu kemahiran hidup, ilmu mengenal tuhan dan penghayatan terhadap asas-asas keimanan juga adalah sangat penting. Pendidikan ini meliputi akidah, ketaatan beribadah dan keseimbangan berakhlak yang tiada bezanya dengan pendidikan Islam kepada individu normal. Tujuannya adalah supaya setiap individu, termasuk OKU tidak tersasar daripada sesuatu nilai dan amalan kerohanian yang dituntut. Walau bagaimanapun, penerapan nilai-nilai ini mempunyai limitasinya yang tersendiri serta memerlukan suatu pendekatan yang sesuai dengan tahap keupayaan mereka. Manakala tugas bimbingan bukan sahaja terletak di atas tanggungjawab ibu bapa semata-mata tetapi perlu disokong oleh masyarakat setempat, para guru, agensi kerajaan dan institusi berkepentingan yang memahami peranan agama dalam kehidupan mereka.

\section{Rujukan}

Ab. Aziz Mohd Zin et al. Dakwah Islam Terhadap Orang Kurang Upaya. Kuala Lumpur: Universiti Malaya, 2009.

Abdul Hafiz Mat Tuah, Zakaria Stapa dan Ahmad Munawar, "Memperkasakan Jati Diri Melayu-Muslim Menerusi Pendidikan Islam dalam Pengajaran Akhlak", Jurnal Hadhari (2012), 31. 
Ahmad al-Qattan, Pendidikan Anak Cemerlang menurut al-Quran dan al-Sunnah, terj. Ahmad Najib Abdullah al-Qari. Selangor: Pustaka Ilmi, 1998.

Al-Bukhārī, Abū 'Abd Allāh Muḥammad bin Ismā'īl. Jāmi' alMusnad al-Sahāhh al-Mukhtașar Min Umūrī Rasul Allāh SAW wa Sunanihi wa Ayyāmih, "Ṣaḥ̄h al-Bukhārī", e.d Muhammad Zuhayr bin Nāṣir al-Nāṣir. Mansurah: Dār Ṭūqā al-Najah, 2001.

Al-Syaibani, Omar Muhammad al-Toumy. Falsafah Pendidikan Islam, terj. Hasan Langgulung. Selangor: Hizbi Sdn. Bhd., 1991.

Azmi Shaari, Noor Hayati Che Harun dan Tengku Noaswita Tengku Besar. "Faktor yang Mempengaruhi Penglibatan Keluarga Penjaga di Sekolah dan Kesannya ke atas Pencapaian Akademik Anak Cacat Penglihatan". Jurnal Pembangunan Sosial (4\&5, Jun \& Disember, 2002), 15-26.

Baum, Sandra, "The Use of Systemic Approach to Adullts with Intellectual Disabilities and their Families: Historical Overview and Current Research", In Sandra Baum and Henrik Lynggaard, Intellectual Disabilities: A Systemic Approach (London: Routledge, 2018), 22-23.

Gulson Begum Khalid dan Mohd Hanafi Mohd Yasin. "Strategi Menjayakan Penglibatan Ibu Bapa di Sekolah Pelajar Berkeperluan Khas". Makalah, Seminar Internasional PascaSiswazah Pendidikan Khas UKM-UPI Siri II, 28 Januari 2012.

Jamila K.A. Mohammed Kutty, Mohd Hanafi Mohd Yasin dan Rosadah Abd Majid. "Pelaksanaan Pengajaran Kemahiran Membaca dan Menulis bagi Murid Murid Pra-Sekolah Bermasalah Pendengaran". Jurnal Pendidikan Bahasa Melayu (2011), 117.

Khairul Hamimah Mohammad Jodi, Mohd Fauzi Hamat dan Hadenan Towpek. "Nilai-nilai Islam dalam Program Pemulihan Banduanita di Penjara", Jurnal Usuluddin 35 (2012), 99-116.

Leonard, Helen et al. "Transition to Adulthood for Young People with Intellectual Disability: The Experience of their Families", Eur Child Adolesc Psychiatry (25, 2016), 1369-1381

Lisle, Kelsey. "Identifying the Negative Stigma Associated with Having a Learning Disability". Honors Thesis, Bucknell University, 2011. 
Mohd Zuri Ghani dan Aznan Che Ahmad. Pengantar Pendidikan Khas. Pulau Pinang: Universiti Sains Malaysia, 2011.

Muhammad Khair Ramadan Yusuf. Kisah Luqman al-Hakim dan Kebijaksanaannya, terj. Ibnu Ghazali, Buku 2. Selangor: Jasmin Enterprise, 2006.

Normah Che Din. "Kepentingan Penilaian Profil dan Keperluan Kanak-kanak Istimewa". Makalah, Seminar Pendidikan AnakAnak Istimewa dalam Islam, Institut Kefahaman Islam Malaysia, Kuala Lumpur, 21-22 Ogos, 2014.

Ramlan Salim. Pengurusan Pendidikan Khas Bermasalah Pembelajaran. Kuala Lumpur: Dewan Bahasa dan Pustaka, 2015.

Saedah Sumrah, Salwan Sudirman dan Roslee Ahmad. "Kaedah Menangani Kanak-kanak Bermasalah Tingkahlaku". Makalah, Seminar Kaunseling Keluarga, Universiti Teknologi Malaysia, Skudai, Johor, 30 Ogos 2008.

Sharifuddin Aisa Osman. "Menangani Gejala Sosial: Peranan Keluarga", dalam Keluarga Islam, Kemahiran Keibubapaan dan Cabaran Semasa, peny. Azrina Sobian (S. elangor: MPH Group Publication, 2008.

Subhi Mahmassani. Konsep Dasar Hak-hak Asasi Manusia: Studi Perbandingan Syariat Islam dan Perundangan Moden. Indonesia: Pt. Tintamas, 1979.

Suppiah Nachiappan et al., Pembelajaran dan Perkembangan Pelajar. Edisi ke-2, Selangor: Oxford Pelajar, 2012..

Wan Nasyruddin Wan Abdullah dan Hisham Ahmad. Aku Bersyukur Anakku Autisme. Kuala Lumpur: Telaga Biru, 2013. 